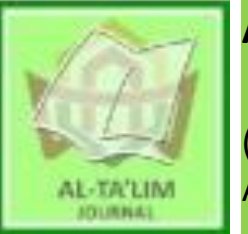

AL-TA'LIM JOURNAL, 27 (3), 2020, (272-281)

(Print ISSN 1410-7546 Online ISSN 2355-7893)

Available online at http://journal.tarbiyahiainib.ac.id/index.php/attalim

\title{
Developing Life Skill Based English Instructional Material in Bilingual Pesantren
}

Received: 05 ${ }^{\text {th }}$ April 2020; Revised: 06 ${ }^{\text {th }}$ April 2020; Accepted: $29^{\text {th }}$ Desember 2020

Permalink/DOI: https://doi.org/10.15548/jt.v27i3.645

\section{Febria Sri Artika *)}

Institut Agama Islam Negeri Bukittinggi, Indonesia

E-mail: febria.artika80@gmail.com

\section{Widya Syafitri}

Institut Agama Islam Negeri Bukittinggi, Indonesia

E-mail: widyasyafitri260780@gmail.com

\section{Risdaneva}

Deakin University, Australia

E-mail: risdaneva@deakin.edu.au

\section{*) Corresponding Author}

\begin{abstract}
This study aims to develop life skill based English instructional material in bilingual Pesantren by using the 4D Model (Define, Design, Develop, and Disseminate). To achieve this aim, this study was conducted using the Research Development (R \& d) method. As part of this method, a series of data collecting techniques involving pre-experimental teaching, interviews, observations, and tests of effectiveness, practicality, and validity, were carried out to gather both quantitative and qualitative data. The participants of this study were one English language teacher and students of Class XI Timur Tengah, Insan Cendikia Boarding School (ICBS) Payakumbuh. The findings of this research reveal that life skill based instructional material is valid and practical. Consequently, the life skill-based materials development can positively give the effective result as the innovation in English instructional material.
\end{abstract}

Keywords: Life skill; bilingual Pesantren; English material.

How to Cite: Artika, F., Syafitri, W., \& Risdaneva, R. (2020). Developing Life Skill Based English Instructional Material in Bilingual Pesantren. Al-Ta lim Journal, 27(3), 271-280. doi:https://doi.org/10.15548/jt.v27i3.645

\section{INTRODUCTION}

The importance of instructional materials as one of the requirements of a successful learning process cannot be denied. A professional teacher should understand that the material has a very important position within the entire curricular component, so it must be well prepared in accordance with competency standards and basic competencies. Kochhar (2012) stated that instructional materials are very effective resources for teaching and learning. Using appropriate instructional materials will also give better achievement to the learners, especially the second language learners (Olayinka, 2016). Students' low selfconfidence, personality traits, and lack of competency are among the causes of failure in mastering a foreign language (Habiburrahim et al., 2020). Therefore, teachers should find the necessary teaching materials to supplement what textbooks provide to broaden concepts and stimulate the interest of students in the subject. In addition, the use of instructional materials makes teaching effective as it encourages learners to actively engage in learning in the classroom (Mathew \& Grover, 2012).

Today, a large number of Pesantren (Islamic boarding schools) use two instructional languages, namely Arabic and English. The instructional materials, particularly English, are assembled in such a 
way that they can be used by the santris (students) as a reference in their everyday lives. According to Zulfikar et al., (2020), a professional teacher should not only be intelligent and smart but also has to be well prepared in terms of various aspects of teaching including the instructional material used in the learning process. Nevertheless, when faced with difficulties using these two foreign languages Indonesian is still used. It is also easier to accomplish the goal of mastering the two foreign languages by making the santris accustomed to using them. One of the Islamic boarding schools which carries out this program is Insan Cendekia Boarding School (more commonly shortened as ICBS) in Payakumbuh, West Sumatera.

The researchers' pre-observation and interview with an English teacher who also serves as the Vice Curriculum Officer informed that ICBS alumnus was academically good, but they were unable to actualize themselves in society to the fullest due to their lack of good life skills. Many personal and social constraints prevented them from developing in society. In addition, the fortnight English speaking obligation still does not guarantee their fluency in English. The next problem is that English language learning material had not been developed based on life skills. The textbooks used were still heavily focusing on grammar, a collection of vocabularies that had to be mastered, and some examples of artificial and simplified short conversations that were not adequate to picture authentic use of English in real life communication. According to Kustati et al., (2020), the contents of English teaching materials is one of the obstacles faced by teachers in a classroom. English-language teachers must endeavor to make better use of teaching materials in their teaching at all levels of education (Ajoke, 2017).

In general, the importance of life skill education for students is to prepare them to deal with and solve their life problems as independent individuals within their community and nation. Slamet (2002) described the significance of life skill education as follows. First, students are provided with qualities, attitudes, and physics to face their future. Second, students are provided with broad insight into career development in an ever-changing working world that they can choose, enter, compete, and advance their careers. Third, students are provided with the ability to practice living in the right way. Fourth, students have the level of independence, openness, cooperation, and accountability needed in their future development. Fifth, students have the ability and skills to overcome various life problems. Moreover, giving life skills to the students will also strengthen the quality of the students and prepare themselves to adapt and get used to the $21^{\text {st }}$ century life skills (Council, 2012; Kivunja, 2015; Mohammadzadeh et al., 2017; Van Laar et al., 2017).

There have been many studies investigating and reporting on life skills. Al Masri et al. (2016) evaluated English textbooks based on elementary-class life skills material and calculated the frequency and percentage of life skills in each text. The study indicates that the distribution of content regarding life skills in textbooks is based on parameters. Additionally, Anderson (2005) and Mahmoudi (2016) examined the view of pupils, teachers, and parents on the importance of life skills and long-term life guidance. The findings of this research indicated that the life skills program and longterm lifetime advice have had a positive impact on the schools. The benefit of life skill education has also affected the world of youth group (Cullinane \& Montacute, 2017; Loeser et al., 2004; O'Hara et al., 2004, and Smith et al. 2005). In addition, the use of Andragogical Learning Model to enhance the drop out students' Life Skill has shown its 'effectiveness (Djibu et al., 2019). These previous studies, however, have explored the area of life skills with different foci and in different contexts from the current study that attempts to develop English instructional material based on life skills in a bilingual Pesantren.

The ICBS students should not only be equipped with knowledge but also be prepared to acquire life skills to solve the 
potential problems in their life. Life skills education is an educational model that develops soft skills and integrates hard skills. Strengthening the soft skills of the students would improve their hard skills and vice versa. People with good character will balance their soft skills and hard competencies in actions within the community. Based on the above issues, it is important to improve English language learning materials based on life skills especially in the context of Pesantren which has introduced a bilingual program so that students can enable and mobilize all the positive values and skills they have acquired to be optimally applied in everyday life and future planning. Their ability in English will also support their life in this AEC (ASEAN Economic Community) era (Syafitri \& Artika, 2019). This consideration is underlying in the researchers' attempt to conduct work under the title Developing Life Skill Based English Instructional Material in a Bilingual Pesantren.

\section{METHOD}

\section{Research Design}

This study was conducted by using the Research Development (R \& D) method. This research method is used to produce a certain product and examine its effectiveness (Dr, 2008). The Four-D model was chosen after adjusting to the characteristics encountered in the field. This model has several advantages: (1) it is more appropriate to be used for the development of learning material, (2) a complete and systematic description, (3) before being tested, teaching materials are revised by the researchers and consulted to the experts, (4) easy to be conducted. The teaching material that was developed is a life skill-based English teaching material at the bilingual boarding school, Insan Cendekia, Payakumbuh, West Sumatera. The researcher adopted the Four-D model proposed by Thiagarajan (1974) which consists of four stages, defining, designing, developing, and disseminating. In the first stage, defining (Preliminary Analysis), the requirements to develop the intended teaching materials were defined and assigned. To do so, the lesson plans and teaching materials were analyzed. At the designing phase, the researchers designed a life skill-based English teaching material. During this stage, evaluation and revision of lesson plans and teaching materials were carried out to produce highquality life skill-based English teaching materials. In the third step, developing, the prototype model design was modified. The tests of validity and practicality of the developed materials were conducted at this period. In the disseminating stage which is before implementing the product, the effectiveness test was carried out to ensure the quality of the teaching model developed. Therefore, to measure the effectiveness of life skill-based English teaching materials, the researchers conducted pre-experimental research.

\section{Research Sample}

The life skill based English instructional material was validated by three expert validators from Institut Agama Islam Negeri Bukittinggi. Then the valid material was first trialed to 5 students with low, medium, and high ability. These students were chosen based on the recommendation of the English teacher. After the pilot trial, the module was then implemented in class XI Timur Tengah, ICBS Payakumbuh which consisted of 24 students. Thus, the subjects of this study were an English teacher and students of Class XI Timur Tengah, ICBS Payakumbuh.

\section{Instruments and Data Collection Techniques}

This study required two types of data, namely qualitative and quantitative data. The qualitative data was obtained from the validators' criticisms, observation, field notes, and interviews between the researchers and teacher and students, while the quantitative data was gained from the results of the validation, effectiveness, and practical analysis, as well as a questionnaire. Thus, the instruments of this study were interview guidelines, observation sheets, effectiveness 
tests, validity, and practicality. The data obtained is used to determine the validity, practicality, and effectiveness of the modules developed.

\section{Data Analysis}

The researchers used the interactive model of Miles et al. (2014) to analyze the qualitative data which were collected from interviewing the teacher and students and classroom observation. This model covers four important elements: data collection, data condensation or reduction, data display, and conclusion drawing and verification.

The validity, reliability, and practicability of the quantitative data were also analyzed following a set of statistical procedures. The validity score of data was classified into 5 criterion-reference as adopted from Sadler (2009).

Table 1: Level of Validity

\begin{tabular}{ll}
\hline \multicolumn{1}{c}{ Interval Score } & \multicolumn{1}{c}{ Category } \\
\hline $81-100$ & Very Valid \\
$61-80$ & Valid \\
$41-60$ & Fair \\
$21-40$ & Less Valid \\
$0-20$ & Not Valid \\
\hline
\end{tabular}

Table 1 shows that the result of validity should at least get 61 to get valid data. Then, the reliability of instruments and the product were identified by using SPSS20 grouped by using the following reliability criteria.

Table 2: Level of Reliability

Interval Score Category

\begin{tabular}{ll}
\hline$<0.21$ & Very Low \\
$0.21-0.40$ & Low \\
$0.41-0.70$ & Fair \\
$0.71-0.90$ & High \\
$0.91-1.00$ & Very High
\end{tabular}

The above table indicates that 0.71 is the minimum score that needs to be obtained to be categorized as a highly reliable instrument or product.

At last, the researchers distributed the practicability questionnaire to the teacher and students to elicit their perceptions toward the use of life skill-based English teaching materials in terms of aspects of ease of use, efficient use of time, and benefits. The score of practicability is classified based on the following categories.

Table 3: Criteria for Practicability (Purwanto, 2000)

\begin{tabular}{ll}
\hline Interval Score & \multicolumn{1}{c}{ Category } \\
\hline $81-100$ & Very practical \\
$61-80$ & Practical \\
$41-60$ & Fair \\
$21-40$ & Less Practical \\
$0-20$ & Not Practical \\
\hline
\end{tabular}

It can be seen from the information in table 3 that the reliability score obtained from processing through software could be grouped into four levels of practicality, from the lowest into the highest one.

\section{RESULTS AND DISCUSSIONS}

This life skill-based English teaching material was developed in Insan Cendekia Boarding School in Payakumbuh, West Sumatera through four steps which include defining, designing, developing, and disseminating.

\section{Defining}

In this study, the researcher analyzed the teacher's lesson plans as well as the textbook used by teachers to give assignments and exercises to students. The analysis was followed up by interviewing both students and teachers. Interviews were conducted to identify issues found in the English textbooks and lesson plans. From the results of the interviews and observations, several problems have been identified: a) the existing materials 
are less relevant to student life; b) the difficulty level of vocabulary is still high; c) the existing materials lack life skill-based components; d) the format, layout, and quality of the book paper are less attractive; e) the teaching steps elaborated in the lesson plan have not overcome the students' difficulties in terms of vocabulary mastery.

\section{Designing}

The second step is designing the instructional material based on life skills. This design is informed by the phenomena found in the lesson plan and the existing instructional material which suggest that there is a lack of life skill-based learning materials noticed in the existing English textbook used in daily teaching. In designing the life skillsbased instructional material, the researchers designed the format, outlined the framework, and developed the framework into a draft. Meanwhile, in designing the lesson plan, the researchers drafted the framework and developed it accordingly.

The validity test of the developed product was then carried out by distributing questionnaires to three experts and they concluded that the instructional material was valid.

\section{Developing}

The third step is developing designed products by testing the validity and practicality of the design.

\section{Validity}

Table 4: Result of textbook validation

\begin{tabular}{llrr}
\multicolumn{4}{c}{ Case Processing Summary } \\
\hline \multirow{4}{*}{ Cases } & N & \multicolumn{1}{c}{$\%$} \\
& Valid & 16 & 100.0 \\
& Excluded $^{\mathrm{a}}$ & 0 & .0 \\
& Total & 16 & 100.0
\end{tabular}

a. List wise deletion based on all variables in the procedure.

Table 4 above shows that there are 16 questions to measure the validation of textbooks and all questions are categorized as valid.

Table 5: Intra Class Correlation of Textbook

\begin{tabular}{lccccccc}
\hline & $\begin{array}{l}\text { Intra } \\
\text { Correlation }\end{array}$ & $\begin{array}{c}\text { Class } \\
\text { ( }\end{array}$ & 95\% Confidence Interval & \multicolumn{3}{c}{ FTest with True Value 0 } \\
\hline & & Lower Bound & Upper Bound & Value & dfl & Df2 & Sig \\
$\begin{array}{l}\text { Single } \\
\text { measures }\end{array}$ & $.921^{\mathrm{a}}$ & .830 & .969 & 36.200 & 15 & 30 & .000 \\
$\begin{array}{l}\text { Average } \\
\text { measures }\end{array}$ & $.972^{\mathrm{c}}$ & .936 & 990 & 36.200 & 15 & 30 & .000 \\
\hline
\end{tabular}

Two-way mixed effects model where people effects are random and measures effects are fixed.

a. The estimator is the same, whether the interaction effect is present or not.

b. Type $\mathrm{C}$ intraclass correlation coefficients using a consistency definition-the between measure variance is excluded from the denominator variance.

c. This estimate is computed assuming the interaction effect is absent because it is not estimable otherwise.

The software results show that the Intra Class Correlation (ICC) of the three validators is very high, as shown in Table 6. This means that the three validators give the textbook high scores. It can therefore be concluded that the textbook is valid and can be used in the learning process. Meanwhile, the reliability of textbooks is also declared to be reliable, as shown in the table below.
Table 6: Reliability of Textbook

\begin{tabular}{|c|c|c|}
\hline $\begin{array}{l}\text { Cronbach's } \\
\text { Alpha }\end{array}$ & $\begin{array}{l}\text { Cronbach's } \\
\text { Alpha Based } \\
\text { on } \\
\text { Standardized } \\
\text { Items }\end{array}$ & $\begin{array}{l}\mathrm{N} \text { of } \\
\text { Items }\end{array}$ \\
\hline .97 & .972 & 3 \\
\hline
\end{tabular}


From the table above, it is clear that Cronbach's alpha coefficient is 0,972 and indicates that the consistency of the question is high. This means that the reliability value of the student book validation instrument is in the high category.mIn addition to the validity and reliability of textbooks, input from experts on textbooks is also provided. While one of the validators suggested adding live pictures and activities, the other validator advised to check and revise the grammatical error, and another encouraged to put attention to the layout. This information is the directive to revise the instructional materials.

The next step was to validate the designed lesson plan. The researcher also requested the assistance of three experts to provide an assessment of the lesson plan feasibility through a questionnaire. Then, the questionnaires were analyzed by using SPSS20 software as depicted in the following table:

\begin{tabular}{llll}
\multicolumn{4}{c}{ Table 7: Validity of Lesson Plan } \\
\hline & N & \% \\
\hline \multirow{2}{*}{ Case } & Valid & 9 & 100.0 \\
& $\begin{array}{l}\text { Excluded } \\
\text { a }\end{array}$ & 0 & .0 \\
& Total & 9 & 100.0
\end{tabular}

a. List wise deletion based on all variables in the procedure.

From Table 7 it is seen that the lesson plan is valid which is proofed by $100 \%$ of the validity point.

\section{Reliability}

Then, the researchers also measured the reliability of the lesson plan which is seen in the following table.

Table 8: Reliability of Lesson Plan

\begin{tabular}{rrr}
\hline $\begin{array}{l}\text { Cronbach's } \\
\text { Alpha }\end{array}$ & $\begin{array}{l}\text { Cronbach's Alpha based } \\
\text { on Standardized Items }\end{array}$ & N of Items \\
\hline .947 & .949 & 3
\end{tabular}

Based on the SPSS20 test, the reliability value of the lesson plan validation instrument is 0.947. This means that the lesson plan is categorized as a highly reliable product. From the above test results, the lesson plan validation instrument has a high level of consistency.

Since there are three experts or raters who validate the lesson plan, it is important to identify the interclass correlation coefficient to measure the extent to which the three experts agree on the validity of the lesson plan. The results of the ICC lesson plan are classified as very high as presented below.

Table 9: Intra Class Correlation Coefficient

\begin{tabular}{|c|c|c|c|c|c|c|c|}
\hline & \multirow[t]{2}{*}{$\begin{array}{l}\text { Intraclass } \\
\text { Correlatio } \\
\mathrm{n}^{\mathrm{b}}\end{array}$} & \multicolumn{2}{|c|}{$\begin{array}{c}95 \% \\
\text { Confidence } \\
\text { Interval }\end{array}$} & \multicolumn{4}{|c|}{ F Test with True Value 0} \\
\hline & & $\begin{array}{l}\text { Low } \\
\text { er } \\
\text { Bou } \\
\text { nd }\end{array}$ & $\begin{array}{l}\text { Up } \\
\text { per } \\
\text { Bo } \\
\text { un } \\
\text { d }\end{array}$ & Value & dfl & df2 & Sig \\
\hline $\begin{array}{l}\text { Single } \\
\text { measu } \\
\text { res }\end{array}$ & $.857^{\mathrm{a}}$ & .629 & $\begin{array}{l}.96 \\
2\end{array}$ & $\begin{array}{l}19.00 \\
0\end{array}$ & 8 & 16 & $\begin{array}{l}.00 \\
0\end{array}$ \\
\hline $\begin{array}{l}\text { Avera } \\
\text { ge } \\
\text { measu } \\
\text { res }\end{array}$ & $.947^{\mathrm{c}}$ & .836 & $\begin{array}{l}.98 \\
7\end{array}$ & $\begin{array}{l}19.00 \\
0\end{array}$ & 8 & 16 & $\begin{array}{l}.00 \\
0\end{array}$ \\
\hline
\end{tabular}

Two-way mixed effects model where people effects are random and measures effects being fixed.

a. The estimator is the same, whether the interaction the effect is present or not.

b. Type $\mathrm{C}$ intraclass correlation coefficients using a consistency definition-the between-measure variance is excluded from the denominator variance.

c. This estimate is computed assuming the interaction the effect is absent because it is not estimable otherwise.

\section{Practicality}

The second activity was to test the practicality of the product. Practicality testing is performed to measure whether a product is ready for use or not. In this case, the practicality of the developed teaching materials was measured by asking 24 students who have used the teaching materials about the use of the materials through a questionnaire. Before this practicality test was carried out, the instrument for measuring practicality was first validated. The results show that the instrument is valid, as follows: 
Table 10: Average of practicality statement

\begin{tabular}{|c|c|c|c|c|}
\hline No & Statement & Average & Percentage & Criteria \\
\hline 1 & $\begin{array}{l}\text { The purpose } \\
\text { of learning } \\
\text { is clear }\end{array}$ & 4.42 & 88 & $\begin{array}{c}\text { Very } \\
\text { practical }\end{array}$ \\
\hline 2 & $\begin{array}{l}\text { The text } \\
\text { available in } \\
\text { the book is } \\
\text { based on } \\
\text { the student's } \\
\text { abilities. }\end{array}$ & 4.21 & 84 & $\begin{array}{c}\text { Very } \\
\text { practical }\end{array}$ \\
\hline 3 & $\begin{array}{l}\text { Activities in } \\
\text { the book } \\
\text { correspond } \\
\text { to the skills } \\
\text { of the } \\
\text { students }\end{array}$ & 4.21 & 84 & $\begin{array}{c}\text { Very } \\
\text { practical }\end{array}$ \\
\hline 4 & $\begin{array}{l}\text { The student } \\
\text { module } \\
\text { provides } \\
\text { students } \\
\text { with } \\
\text { information } \\
\text { about what } \\
\text { and what } \\
\text { the students } \\
\text { will do in } \\
\text { the future } \\
\text { and/or at } \\
\text { other times }\end{array}$ & 4.04 & 81 & $\begin{array}{c}\text { Very } \\
\text { practical }\end{array}$ \\
\hline 5 & $\begin{array}{l}\text { This student } \\
\text { book is } \\
\text { useful to } \\
\text { students } \\
\text { because it } \\
\text { helps } \\
\text { students } \\
\text { learn better. }\end{array}$ & 4.17 & 83 & $\begin{array}{c}\text { Very } \\
\text { practical }\end{array}$ \\
\hline 6 & $\begin{array}{l}\text { The } \\
\text { instructions } \\
\text { in this book } \\
\text { are easy to } \\
\text { understand. }\end{array}$ & 4.67 & 93 & $\begin{array}{c}\text { Very } \\
\text { practical }\end{array}$ \\
\hline 7 & $\begin{array}{l}\text { This student } \\
\text { module is } \\
\text { easy to } \\
\text { carry due to } \\
\text { its practical } \\
\text { size. }\end{array}$ & 4.63 & 93 & $\begin{array}{c}\text { Very } \\
\text { practical }\end{array}$ \\
\hline 8 & $\begin{array}{l}\text { This book } \\
\text { isn't dense } \\
\text { and is } \\
\text { therefore } \\
\text { inexpensive } \\
\text { for students }\end{array}$ & 4.71 & 94 & $\begin{array}{c}\text { Very } \\
\text { practical }\end{array}$ \\
\hline 9 & $\begin{array}{l}\text { The } \\
\text { language } \\
\text { used in the } \\
\text { book is easy } \\
\text { to } \\
\text { understand }\end{array}$ & 4.38 & 88 & $\begin{array}{c}\text { Very } \\
\text { practical }\end{array}$ \\
\hline
\end{tabular}

As can be seen from Table 10, the average practicality of teaching materials is 4.38 with a percentage of 88 and is in a very practical category. It means that the life skillbased textbook is recommended to be used by the students in ICBS. Then, the practicality of the textbook was assessed by using SPSS 20 .

Table 11: Practicality of the Textbook Cronbach's Alpha $\mathrm{N}$ of Items

\begin{tabular}{l}
.852 \\
\hline
\end{tabular}

From the table above, it is clear that the practicality Instrument is 0.852 . It indicates that the reliability value of the teaching material practicality instrument based on life skills is higher than that of $\mathrm{R}$ table $* \mathrm{~N} * 0.404$ and is in the category of high reliability. Moreover, the practicality of this life skills-based textbook is also illustrated through the Intra Class Correlation (ICC) scores as presented in the following table.

Table 12: Intra Class Correlation of the textbook

\begin{tabular}{|c|c|c|}
\hline \multirow{2}{*}{$\begin{array}{l}\text { Intra } \\
\text { Class } \\
\text { Corre } \\
\text { lation } \\
\text { b }\end{array}$} & $\begin{array}{l}95 \% \\
\text { Confiden } \\
\text { ce } \\
\text { Interval }\end{array}$ & Value 0 \\
\hline & $\begin{array}{ll}\text { Lo } & \text { Up } \\
\text { we } & \text { per } \\
\text { r } & \text { Bo } \\
\text { Bo } & \text { un } \\
\text { un } & \text { d }\end{array}$ & $\begin{array}{l}\text { Valu } \\
\text { e }\end{array}$ \\
\hline
\end{tabular}

\begin{tabular}{lrrrrrrr}
\hline Singl & $.389^{\mathrm{a}}$ & .24 & .58 & 6.74 & 2 & 18 & .00 \\
$\mathrm{e}$ & & 3 & 3 & 1 & 3 & 4 & 0 \\
meas & & & & & & & \\
ures & & & & & & & \\
& & & & & & & \\
Aver & $.852^{\mathrm{c}}$ & .74 & .92 & 6.74 & 2 & 18 & .00 \\
age & & 3 & 6 & 1 & 3 & 4 & 0 \\
meas & & & & & & & \\
ures & & & & & & & \\
& & & & & & &
\end{tabular}

Table 12 shows that the average ICC is 0.852 which categorizes the textbook as highly practical. This means that class XI students agree that this textbook is both practical and ready to use. 


\section{Dissemination}

The last stage is dissemination in which the teaching model, life skill based instructional material, was tested for its effectiveness. Before conducting the dissemination, a number of revisions were done to the product. The revisions were made based on feedback and guidance from the validating experts. After the necessary revisions were completed, the researcher held pre-experimental research to determine the effectiveness of the product. The experiment was conducted in Class XI Timur Tengah, Insan Cendikia Boarding School Payakumbuh Islamic Boarding School. The pretest was administered to determine students' understanding of life skills prior to treatment. Pretest was done before applying the life skill-based textbook, while post-test was managed after implementing the life skillbased materials as the instructional materials. The following is the average value obtained from pre-test and post-test results.

Table 13: Average of Pre-test and Post test results

\begin{tabular}{|c|c|c|c|}
\hline $\mathrm{No}$ & Name & Pre-Test & Post-Test \\
\hline 1 & AS & 45 & 85 \\
\hline 2 & AP & 45 & 90 \\
\hline 3 & AAR & 50 & 75 \\
\hline 4 & AY & 50 & 80 \\
\hline 5 & DF & 50 & 85 \\
\hline 6 & GK & 65 & 90 \\
\hline 7 & HSS & 45 & 75 \\
\hline 8 & JR & 60 & 75 \\
\hline 9 & MAAI & 40 & 95 \\
\hline 10 & $\mathrm{MF}$ & 90 & 95 \\
\hline 11 & MHY & 45 & 75 \\
\hline 12 & MHA & 75 & 85 \\
\hline 13 & MRI & 65 & 80 \\
\hline 14 & MRA & 75 & 75 \\
\hline 15 & MR & 55 & 75 \\
\hline 16 & MHN & 70 & 85 \\
\hline 17 & $\mathrm{RR}$ & 80 & 85 \\
\hline 18 & RA & 60 & 95 \\
\hline 19 & RRZ & 45 & 85 \\
\hline 20 & $\mathrm{RN}$ & 60 & 90 \\
\hline 21 & $\mathrm{TH}$ & 50 & 80 \\
\hline 22 & WA & 55 & 75 \\
\hline 23 & $\mathrm{ZA}$ & 40 & 95 \\
\hline \multirow[t]{2}{*}{24} & MAC & 40 & 55 \\
\hline & Average & 56 & 83 \\
\hline
\end{tabular}

Table 13 shows that the students' scores increase in the post-test compared to that in the pre-test. This increase in the students' achievement indicates that the
English textbook based on life skills is more effective than the textbook they previously used. Following the suggestions and feedbacks from the validators regarding clear illustration, layout, learning activities, and relevant topics on daily life based on Islamic context have created effective instructional material.

The finding of this research denoting that the use of effective instructional material affects the quality and results of the learning process is in line with the perspectives proposed by other researchers (Nafiah, 2020; Olumorin et al., 2010; Surdyanto \& Kurniawan, 2020). Moreover, the view of the effectiveness of having life skill education as the basic concept in the instructional material has also been proven by other scholars (Mujib \& Madkur, 2016; Rodhi, 2017, Saravanakumar, 2020).

\section{CONCLUSIONS AND RECOMMENDATION}

The Life Skill-based English instruction material developed in this study was found to be highly valid and very practical after being used in the classrooms of Insan Cendekia boarding school in Payakumbuh, West Sumatera. Three experts validated this product, with an ICC average value of 0.972 , which means that the validity value is high. In addition, the results of the practicality test conducted to 24 students as users of the product also indicate high level practicality, 0.852. Furthermore, designing the product material with interesting layout and design also increased the students,' interest in studying compared to their previous handbook that was black and white with newsprint paper. Finally, the average final score of the pre-test and post-test of the students involved in pre-experimental teaching which indicates the value of the efficacy of this life skill learning content has shown that the product is effective to be implemented in achieving the objectives of ICBS as a bilingual boarding school.

The students of Insan Cendikia Boarding School (ICBS) assumed that this model was useful for them in learning 
English, with the expectation that English teachers would continue using this life skillsbased model. In addition, life skills are also part of the curriculum that must be integrated into all education units. This model offers all facets of life for students; personal, academic, social skills, or majors. This means that the life skills materials provided in the form of English teaching materials are not only useful for their academic background as students, but also for their lives outside the school.

Based on the findings of the research, the researchers expect English teachers to be able to apply life skills-based English teaching materials to help students become individuals with personal, social, academic and vocational skills. However, this study has a limitation that the product dissemination cannot be applied in a wider area. Therefore, it is recommended that other researchers develop such this product for other types of skills and broader subjects.

\section{REFERENCES}

Ajoke, A. R. (2017). The Importance of instructional materials in teaching English as a Second Language. International Journal of Humanities and Social Science Invention, 6(9), 36-44.

Al Masri, A., Smadi, M., Aqel, A., \& Hamed, W. (2016). The Inclusion of Life Skills in English Textbooks in Jordan. Journal of Education and Practice, 7(16), 81-96.

Anderson, J. (2005). The Perceptions of Students, Teachers, and Parents Regarding the Value of the LIFESKILLS and Lifelong Guidelines Program.

Council, N. R. (2012). Education for life and work: Developing transferable knowledge and skills in the 21st century. National Academies Press.

Cullinane, C., \& Montacute, R. (2017). Life lessons: Improving essential life skills for young people.

Djibu, R., Shofwan, I., \& Basrun, M. C. (2019). Development of Andragogical Learning Model to Improve Life Skill for Teenagers Who Drop Out of School in Gorontalo City. Int. J. Sci. Technol. Res, 8(10).

Dr, P. (2008). Sugiyono, Metode Penelitian Kuantitatif Kualitatif dan $R \& D$. CV. Alfabeta, Bandung.

Habiburrahim, H., Risdaneva, R., Putri, G., Dahliana, S., \& Muluk, S. (2020). The Effects of Anxiety Toward Acehnese Students' English Speaking Ability. The Qualitative Report, 25(1), 254-270.

Kivunja, C. (2015). Teaching students to learn and to work well with 21 st century skills: Unpacking the career and life skills domain of the new learning paradigm. International Journal of Higher Education, 4(1), 1-11.

Kochhar, S. K. (2012). The teaching of social studies. India. Sterling Publishers Private Limited, New Delhi.

Kustati, M., Yusuf, Y. Q., Hallen, H., AlAzmi, H., \& Sermal, S. (2020). EFL Teachers' Attitudes towards Language Learners: A Case of Multicultural Classrooms. International Journal of Instruction, 13(1), 353-370.

Loeser, D. M., Bailey, S. J., Benson, R. L., \& Deen, M. Y. (2004). Measuring impacts with young audiences: Adapting a lifeskills Instrument for Use with third-to fifth-grade youth. Journal of Extension.

Mahmoudi, A. (2016). Educational achievement with mega cognitive insight in reading strategies. The Online Journal of New Horizons in Education-January, 6(1).

Mathew, M. C., \& Grover, J. W. (2012). Choosing Blindly: Instructional materials, Teacher effectiveness and the Common core. A Report of the Brown Center on Education Policy at Brookings Institution.

Miles, M. B., Huberman, A. M., \& Saldaña, J. (2014). Qualitative data analysis: A methods sourcebook. 3rd. Thousand Oaks, CA: Sage. 
Mohammadzadeh, M., Awang, H., SHAHAR, H. K., \& Ismail, S. (2017). Life skills education for Malaysian institutionalised adolescents: Knowledge, needs and priorities: A qualitative pilot study. Iranian Journal of Public Health, 46(12), 1739.

Mujib, A., \& Madkur, A. (2016). Islamicbased Life Skill Education on State Vocational High Schools in Metro. The First International Conference on Law, Economics and Education.(Metro: Universitas Muhammadiyah Metro, 2016), 43-47.

Nafiah, U. (2020). Developing English modules with integrated Islamic values and the Jambi local wisdom. Studies in English Language and Education, 7(1), 96-112.

O'Hara, S., Bourner, T., \& Webber, T. (2004). The practice of self-managed action learning. Action Learning: Research and Practice, 1(1), 29-42.

Olayinka, A.-R. B. (2016). Effects of Instructional Materials on Secondary Schools Students' Academic Achievement in Social Studies in Ekiti State, Nigeria. World Journal of Education, 6(1), 32-39.

Olumorin, C. O., Yusuf, A., Ajidagba, U. A., \& Jekayinfa, A. A. (2010). Development of Instructional materials from local resources for art-based courses. Asian Journal of Information Technology, 9(2), 107-110.

Purwanto, M. N. (2000). Prinsip-prinsip dan teknik evaluasi pengajaran. Remaja Rosdakarya.

Rodhi, M. (2017). Pengembangan Materi Pendidikan Kecakapan Hidup pada Buku Pelajaran Bahasa Inggris dengan Model Pembelajaran Literasi pada Kelas $\mathrm{X}$ MAN Mojosari dan MAN Sooko Mojokerto. Progressa: Journal of Islamic Religious Instruction, 1(1), 1324.
Sadler, D. R. (2009). Indeterminacy in the use of preset criteria for assessment and grading. Assessment \& Evaluation in Higher Education, 34(2), 159-179.

Saravanakumar, A. R. (2020). Life Skill Education through Lifelong Learning. Lulu. com.

Slamet, P. H. (2002). Pendidikan kecakapan hidup: konsep dasar. Jurnal Pendidikan Dan Kebudayaan, 8(37), 23-37.

Smith, T. A., Genry, L. S., \& Ketring, S. A. (2005). Evaluating a youth leadership life skills development program. Hindsight, 2(2.29), 31.

Surdyanto, A., \& Kurniawan, W. (2020). Developing critical reading module using integrated learning content and language approach. Studies in English Language and Education, 7(1), 154-169.

Syafitri, W., \& Artika, F. S. (2019). English as lingua franca and asean economic community (AEC): a perspective of islamic economy faculty in building strong muslim students in iain Bukittinggi. ISLAM REALITAS: Journal of Islamic \& Social Studies, 5(1), 71-81.

Thiagarajan, S. (1974). Instructional development for training teachers of exceptional children: A sourcebook.

Van Laar, E., Van Deursen, A. J. A. M., Van Dijk, J. A. G. M., \& De Haan, J. (2017). The relation between 21 st-century skills and digital skills: A systematic literature review. Computers in Human Behavior, 72, 577-588.

Zulfikar, T., Emawati, E., \& Al-Azmi, H. (2020). Empowering Education: Exploring Teachers' Classroom Practices in Vocational Schools. Al-Ta Lim Journal, 27(2), 127-139. 